\title{
Influence of Relative Humidity on Germination and Metal Accumulation in Vigna radiata Exposed to Metal-based Nanoparticles
}

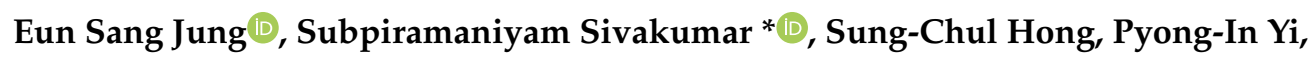 \\ Seong-Ho Jang and Jeong-Min Suh
}

\author{
Department of Bioenvironmental Energy, College of Natural Resources and Life Science, Pusan National \\ University, Miryang-si, Gyeongsangnam-do 50463, Korea; esjung@pusan.ac.kr (E.S.J.); \\ schong@pusan.ac.kr (S.-C.H.); watec@pusan.ac.kr (P.-I.Y.); jangsh@pusan.ac.kr (S.-H.J.); \\ suhjm@pusan.ac.kr (J.-M.S.) \\ * Correspondence: ssivaphd@yahoo.com; Tel.: +82-63-8500838; Fax: +82-63-850-834
}

Received: 13 January 2020; Accepted: 11 February 2020; Published: 12 February 2020

\begin{abstract}
The effect of single $\left(0.1,1\right.$, and $\left.10 \mathrm{mg} \mathrm{L}^{-1}\right)$ and binary mixtures $(0.1+0.1,1+1$, and $10+$ $\left.10 \mathrm{mg} \mathrm{L}^{-1}\right)$ of metal-based nanoparticles $(\mathrm{CdO}$ and $\mathrm{CuO})$ on the germination of Vigna radiata was studied under two humidity ranges $(70 \%$ and $80 \%)$. Filter paper-based tests were conducted. The surface-sterilized seeds were exposed to $\mathrm{CdO}$ and $\mathrm{CuO}$ under controlled environmental conditions ( $70 \%$ and $80 \%$ humidity at $35^{\circ} \mathrm{C}$ ). Germination rates were scored after $24 \mathrm{~h}$ and $48 \mathrm{~h}$. The accumulation of metals was tested in seedlings after $48 \mathrm{~h}$ using inductively coupled plasma mass spectrometry. Compared with 70\% humidity, the germination rate was higher under $80 \%$ humidity in all tested conditions. The germination rate of the $\mathrm{CdO}+\mathrm{CuO}$ treatment was less than that of the single metal exposure under both humidities $(70 \%$ and $80 \%)$ at $48 \mathrm{~h}$. By two-way analysis of variance (ANOVA), we found that germination was greatly influenced by humidity. The accumulation of metal was higher in the $\mathrm{CuO}$ test than in the $\mathrm{CdO}$ test. Metal accumulation was concentration and humidity dependent, except for $\mathrm{Cd}$ accumulation in the $\mathrm{CdO}+\mathrm{CuO}$ treatment. Here we show that the germination of seeds depends on the humidity and concentration of metal oxide nanoparticles. Understanding these strategies in seeds might help to avoid environmental and chemical stress and improve crop yield.
\end{abstract}

Keywords: metal-based nanoparticle; germination; accumulation; $\mathrm{CuO} ; \mathrm{CdO}$

\section{Introduction}

The use of metal-based nanoparticles (M-NPs) in many sectors (such as textile, electronics, medical, cosmetics, and environmental treatment processes) leads to their release into water and soil environments. Nanoparticles are just 1 to $100 \mathrm{~nm}$ in diameter and this small size might induce undesired effects in soil and water, affecting animals and plants. Furthermore, due to their minute size, nanoparticles can penetrate the plant cell wall and disrupt cellular functions. Based on their specific properties (size, surface characteristics, reactivity, and optical sensitivity) [1], many toxic effects of nanoparticles have been recorded in the literature, including tissue inflammation [2] and altered cellular oxidative metabolism [3], which can lead to cell damage and death [4]. In toxicity experiments, researchers must choose the test organism, the test endpoint, and the sensitivity of the organisms. The typical endpoints in plant ecotoxicology tests are seed germination, growth, biomass, and enzyme activity, among others. Many previous studies have investigated these aspects using metal-based nanoparticles [5], typically using the endpoint seed germination in phytotoxicity assay, where the seeds are exposed to the M-NPs throughout germination [6]. 
Seeds are protected against various stresses; however, they become stress-sensitive during the vegetative development stages. Therefore, many toxicity studies on seed germination have reported the effect of M-NPs as well as accumulation in biomass [5,6]. There have been reports of the inhibition of seed germination, seedling growth, and root elongation of various plant species by the nanoparticles $\mathrm{CdS}$ [7-9], $\mathrm{CuS}$ [8], $\mathrm{CuO}$ [9,10], $\mathrm{ZnO}$ [11], as well as rare earth nanoparticles [12]. However, to better understand these effects, studies are needed that apply a mixture of metals. We identified two such studies in the literature. Ko et al. [13,14] have studied the seed germination of Brassica, and another study addressed the cell count and chlorophyll content of algae. In both studies, Brassica seeds and algae were exposed to individual and binary mixtures of various metal oxide nanoparticles (e.g., $\mathrm{CuO}, \mathrm{NiO}, \mathrm{ZnO}, \mathrm{TiO}_{2}, \mathrm{Fe}_{2} \mathrm{O}_{3}$, and $\mathrm{Co}_{3} \mathrm{O}_{4}$ ). In addition, in plant ecology, environmental factors (e.g., temperature, humidity, and light) are important parameters for the growth of plants. High relative humidity enhances the uptake of metals from the air by leaves due to hydration of the cuticle [15]. In a controlled environment, without any chemical stress, the optimum temperature and relative humidity for germination of black gram seeds were $35^{\circ} \mathrm{C}$ and $80 \%$, respectively [16]. Furthermore, there are no reports available in the literature on the influence of relative humidity on the sprouting of seeds when exposed to a single and binary mixture of nanoparticles. Therefore, this study uses metal oxide nanoparticles $(\mathrm{CuO}$ and $\mathrm{CdO})$ as pollutants exposed to Vigna radiata. Additionally, two studies tested the germination of Lathyrus sativus L [9] and Coriandrum sativum [17] seeds pretreated with M-NPs $(\mathrm{CuS}$ and $\mathrm{CdO})$ for 2 to $6 \mathrm{~h}$. Binary mixtures of these M-NPs and the humidity effect was not tested in these studies. Therefore, these two aspects are considered in this study.

\section{Materials and Methods}

\subsection{Chemicals and Seeds}

The CdO (CAS No. 7740-50-8, 99.9\% purity) and CuO (CAS No. 1306-19-0, 98.9\% purity) NP powders (partially passivated with oxygen by the manufacturer) were purchased and used in this study (American elements, USA). The properties of the nanoparticles are given on the manufacturer's website, and the compilation of some of the properties is listed in Table 1. The stock solutions (1000 ppm) were prepared by mixing $1 \mathrm{~g}$ of $\mathrm{Cd}$ and $\mathrm{Cu}$ in Millipore water. For optimum uniform suspensions, both M-NPs were sonicated (Hwashin Tech, Powersonic 610) for $1 \mathrm{~h}$ and stirred using a magnetic stir plate. In single effect treatments, the concentrations were $0,0.1,1$, and $10 \mathrm{mg} \mathrm{L}^{-1} \mathrm{CuO}$ or $\mathrm{CdO}$ and the binary mixture treatments were $0,0.1+0.1,1+1$, and $10+10 \mathrm{mg} \mathrm{L}^{-1}$ of $\mathrm{CdO}+\mathrm{CuO}$ prepared from stock solutions. To avoid aggregation during exposure, the suspensions of single and combined metal solutions were stirred using the method described previously. The certified seeds of Vigna radiata were purchased from the local seed store. The uniform size, color, and weight of the seeds were chosen for this study. The seeds were surface sterilized with $0.1 \%$ mercuric chloride for $2 \mathrm{~min}$, washed thoroughly with tap water, and then by Millipore water for $30 \mathrm{~min}$.

Table 1. Physicochemical characteristics of the nanoparticles used in this study.

\begin{tabular}{ccc}
\hline Physicochemical Property & CdO & CuO \\
\hline Molecular mass & 128.4 & 79.55 \\
Appearance & White & Black to brown \\
Melting point $\left({ }^{\circ} \mathrm{C}\right)$ & $900-1000$ & 1201 \\
Boiling point $\left({ }^{\circ} \mathrm{C}\right)$ & 1559 & 2000 \\
Density $\left(\mathrm{g} / \mathrm{cm}^{3}\right)$ & 8.15 & 6.31 \\
Exact mass $(\mathrm{g} / \mathrm{mol})$ & 129.9 & 78.9 \\
Particle Size $(\mathrm{nm})$ & $20-80$ & $1-30$ \\
Specific surface area $\left(\mathrm{m}^{2} / \mathrm{g}\right)$ & $10-50$ & $100-200$ \\
\hline
\end{tabular}




\subsection{Germination Experiment}

The seed germination test was carried out on a moist filter paper (ISTA, 1997). The surface-sterilized seeds were placed on two sheets of filter paper (Whatman No. 1) contained in $90 \mathrm{~mm}$ sterile Petri dishes. Each Petri plate was moistened uniformly with $5 \mathrm{~mL}$ of a single and binary mixture of $\mathrm{CdO}$ and $\mathrm{CuO}$ concentrations, as mentioned above. Control seeds were irrigated with distilled water. All concentrations were carried out in triplicate (each containing ten seeds). No additional solution was added during this test. The experiment was conducted in a growth chamber (LabTech, LGC-4201, South Korea) at two relative humidities (70\% and $80 \% \pm 1 \%$ ) at a constant temperature of $35 \pm 0.1{ }^{\circ} \mathrm{C}$ under a $16 \mathrm{~h}$ light (2200 lux)/8 h dark cycle for $48 \mathrm{~h}$. Cumulative germination percentage (\%) was recorded at 24 and $48 \mathrm{~h}$ after exposure. The emergence of the radicle from the seed was considered as germinated. The results are expressed as the percent germination and relative germination rate (after $48 \mathrm{~h})$ :

Percentage germination $(\%)=($ Number of germinated seeds $\times 100) /$ total number of seeds. Relative germination rate $=$ Germination rate in treatment $/$ germination rate in control.

Finally, the sprouted plants were carefully removed using forceps at the end of the experiment for the accumulation test.

\subsection{Metal Accumulation}

At the end of the experiment $(48 \mathrm{~h})$, all of the sprouted plant samples were washed with running tap water and then immediately rinsed several times with Milli-Q water (Puris, Expe-UP, South Korea) to remove the M-NPs associated on the plant surface. Prior to the estimation of dry weight and accumulation of $\mathrm{Cd}$ and $\mathrm{Cu}$, the seedling samples were air-dried for 2 days and then dried in an oven at $60-70{ }^{\circ} \mathrm{C}$ for $12 \mathrm{~h}$. The known weight of previously ground and dried plant samples were digested with $\mathrm{HNO}_{3}(65 \%)$ and $\mathrm{HCl}(37 \%)$ at a ratio of 3:1. The mixtures were boiled at $100{ }^{\circ} \mathrm{C}$ until the sample had completely dissolved (maximum $4-5 \mathrm{~h}$ ). The digested samples were then cooled and made up to $50 \mathrm{~mL}$ using Milli-Q water. All samples were stored at $4{ }^{\circ} \mathrm{C}$ until further analysis. The plant digestives were analyzed for elemental concentration using inductively coupled plasma mass spectrometry (ICP-MS, Leemans Labs, USA).

\subsection{Statistical Analysis}

Duncan's multiple range test was performed to determine the significance of results $(p<0.05)$ when comparing the control and M-NP treatments. A two-way ANOVA was performed to compare the exposure concentrations under two humidities and M-NP mixtures. SPSS software (Version 25) was used for all analyses.

\section{Results}

The percent germination ( 24 and $48 \mathrm{~h}$ ) and relative germination rates of $V$. radiata are shown in Table 2 and Figure 1a-c. At $80 \%$ humidity, at an early stage $(24 \mathrm{~h})$, the germination rate significantly differed $(p<0.05)$ between control and single and binary mixtures. However, when we compared the germination percentage at the end of the experiment, we found no difference between seeds that were exposed to single M-NPs (nano $\mathrm{CdO}$ and nano $\mathrm{CuO}$ ) and the control. This significant difference $(p<0.05)$ was maintained in all concentrations of binary mixtures at the end of the experiment $(48 \mathrm{~h})$. All control seeds (100\%) germinated within $24 \mathrm{~h}$, but none of the treatments achieved this value except, $\mathrm{CuO} 0.1 \mathrm{mg} \mathrm{L}^{-1}$. The lowest and highest germination percentages for $\mathrm{CdO}$ exposure were $93 \%$ $\left(10 \mathrm{mg} \mathrm{L}^{-1}\right)$ and $100 \%\left(0.1\right.$ and $\left.1 \mathrm{mg} \mathrm{L}^{-1}\right)$; these values for $\mathrm{CuO}$ exposure were $96.7 \%\left(10 \mathrm{mg} \mathrm{L}^{-1}\right)$ and $100 \%\left(0.1\right.$ and $\left.1 \mathrm{mg} \mathrm{L}^{-1}\right)$; and $80 \%\left(10 \mathrm{CdO}+10 \mathrm{CuO} \mathrm{mg} \mathrm{L}^{-1}\right)$ and $93.3 \%\left(1 \mathrm{CdO}+1 \mathrm{CuO} \mathrm{mg} \mathrm{L}^{-1}\right)$ for $\mathrm{CdO}+\mathrm{CuO}$ exposure. 
Table 2. The effect of a single and binary mixture of $\mathrm{CdO}$ and $\mathrm{CuO}$ on seed germination (\%) (after 24 and $48 \mathrm{~h})$ in filter paper tests at two humidity conditions. Results are given as mean $\left({ }^{*} p<0.05 \mathrm{vs}\right.$. control) and means following with different letters (a to d) in each column are significant at $5 \%$ level of probability.

\begin{tabular}{|c|c|c|c|c|c|}
\hline \multirow{2}{*}{\multicolumn{2}{|c|}{ Concentration $\left(\mathrm{mg} \mathrm{L}^{-1}\right)$}} & \multicolumn{2}{|c|}{ Germination (\%) } & & \\
\hline & & \multicolumn{2}{|c|}{$80 \%$ humidity } & \multicolumn{2}{|c|}{$70 \%$ humidity } \\
\hline & & $24 \mathrm{~h}$ & $48 \mathrm{~h}$ & $24 \mathrm{~h}$ & $48 \mathrm{~h}$ \\
\hline \multicolumn{2}{|c|}{ Control } & $100.0^{\mathrm{a}}$ & $100.0^{\mathrm{a}}$ & $66.7^{\mathrm{a}}$ & $70.0^{\mathrm{a}}$ \\
\hline \multirow{3}{*}{$\mathrm{CdO}$} & 0.1 & $93.3^{b}$ & $100.0^{\mathrm{a}}$ & $60.0^{\mathrm{a}}$ & $63.3^{a}$ \\
\hline & 1 & $80.0^{c}$ & $100.0^{\mathrm{a}}$ & $40.0^{\mathrm{ab}}$ & $43.3^{\mathrm{ab}}$ \\
\hline & 10 & $70.0^{\mathrm{d}}$ & $93.3^{a}$ & $23.3^{b}$ & $23.3^{b}$ \\
\hline \multirow{3}{*}{$\mathrm{CuO}$} & 0.1 & $100.0^{\mathrm{a}}$ & $100.0^{\mathrm{a}}$ & $63.3^{\mathrm{a}}$ & $66.7^{\mathrm{a}}$ \\
\hline & 1 & $90.0^{\mathrm{b}}$ & $100.0^{\mathrm{a}}$ & $60.0^{a}$ & $66.7^{\mathrm{a}}$ \\
\hline & 10 & $53.3^{c}$ & $96.7^{\mathrm{a}}$ & $60.0^{\mathrm{a}}$ & $63.3^{\mathrm{a}}$ \\
\hline \multirow{3}{*}{$\mathrm{CdO}+\mathrm{CuO}$} & $0.1+0.1$ & $70.0^{\mathrm{b}}$ & $90.0^{\mathrm{ab}}$ & $56.7^{\mathrm{a}}$ & $60.0^{\mathrm{a}}$ \\
\hline & $1+1$ & $70.0^{\mathrm{b}}$ & $93.3^{a}$ & $56.7^{\mathrm{a}}$ & $60.0^{\mathrm{a}}$ \\
\hline & $10+10$ & $50.0^{\mathrm{c}}$ & $80.0^{\mathrm{c}}$ & $30.0^{b}$ & $30.0^{b}$ \\
\hline
\end{tabular}
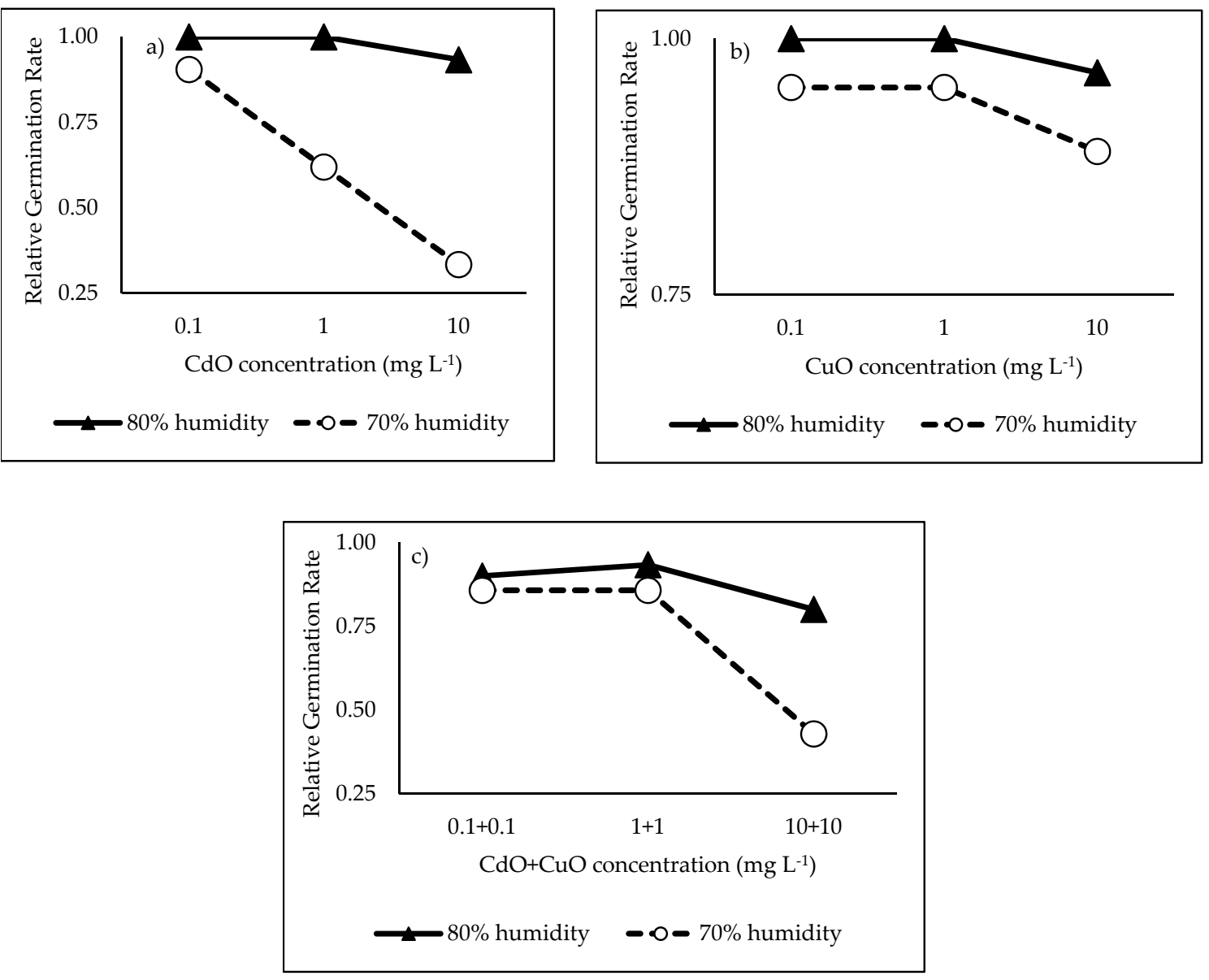

Figure 1. Relative germination rate (after $48 \mathrm{~h}$ ) (germination rate in treatment / germination rate in control) of $V$. radiata seeds exposed to $(\mathbf{a}) \mathrm{CdO},(\mathbf{b}) \mathrm{CuO}$, and (c) $\mathrm{CdO}+\mathrm{CuO}$ at two huminities.

At $70 \%$ humidity, none of the treatments $(\mathrm{CdO}, \mathrm{CuO}$, and $\mathrm{CdO}+\mathrm{CuO})$ achieved $100 \%$ within $48 \mathrm{~h}$. The maximum germination rate $(70 \%)$ was achieved in the control. The maximum germination in $\mathrm{CdO}$ exposure was $63.3 \%\left(0.1 \mathrm{mg} \mathrm{L}^{-1}\right), \mathrm{CuO}$ exposure was $66.7 \%\left(0.1\right.$ and $\left.1 \mathrm{mg} \mathrm{L}^{-1}\right)$, and the binary mixture 
of metal $(\mathrm{CdO}+\mathrm{CuO})$ was $60 \%(0.1 \mathrm{CdO}+0.1 \mathrm{CuO}$ and $1 \mathrm{CdO}+1 \mathrm{CuO})$ at the end of the experiment $(48 \mathrm{~h})$. At the highest exposure concentrations of $\mathrm{CdO}\left(10 \mathrm{mg} \mathrm{L}^{-1}\right)$ and $\mathrm{CdO}+\mathrm{CuO}\left(10+10 \mathrm{mg} \mathrm{L}^{-1}\right)$, we detected a significant $(p<0.05)$ difference compared with the control after $48 \mathrm{~h}$ of exposure.

By two-way ANOVA (Table 3), we found that the humidity was the major factor influencing the germination of seeds either exposed to single M-NPs or exposed to binary M-NPs. Similarly, the $\mathrm{CdO}$ and $\mathrm{CdO}+\mathrm{CuO}$ concentrations also showed a significant effect but not for the case of $\mathrm{CuO}$. Furthermore, the significant interactive effects of concentration and humidity on percent germination were detected only in the $\mathrm{CdO}$ treatment.

Table 3. Results of two-way ANOVA on the interaction between concentration $(\mathrm{CdO}, \mathrm{CuO}$, and $\mathrm{CdO}+$ $\mathrm{CuO}$ ) and humidity on the germination of $V$. radiate seeds. (Df - degrees of freedom, F- F statistic and $\mathrm{P}$ $-p$ value).

\begin{tabular}{ccccc}
\hline Exposure & Source of Variation & Df & F & P \\
\hline $\mathrm{CdO}$ & Concentration & 3 & 6.667 & 0.004 \\
& Humidity & 1 & 108.516 & 0.000 \\
& Concentration vs humidity & 3 & 3.914 & 0.028 \\
\hline $\mathrm{CuO}$ & Concentration & 3 & 0.253 & 0.858 \\
& Humidity & 1 & 60.840 & 0.000 \\
& Concentration vs humidity & 3 & 0.040 & 0.989 \\
\hline $\mathrm{CdO}+\mathrm{CuO}$ & Concentration & 3 & 10.591 & 0.000 \\
& Humidity & 1 & 84.045 & 0.000 \\
& Concentration vs humidity & 3 & 1.500 & 0.253 \\
\hline
\end{tabular}

The relative germination rate data are summarized in Figure 1. The relative germination rate did not show any difference at $80 \%$ humidity test in all single $(\mathrm{CdO}$ and $\mathrm{CuO})$ and binary $(\mathrm{CdO}+$ $\mathrm{CuO}$ ) exposures (Figure 1a-c). Similarly, at 70\% humidity, $\mathrm{CuO}$ exposure had no significant inhibitory effect (Figure 1b). However, at $70 \%$ humidity, the results clearly showed that the inhibition began from $1 \mathrm{mg} \mathrm{L}^{-1}$ of $\mathrm{CdO}$ (Figure $1 \mathrm{a}$ ) and $10+10 \mathrm{mg} \mathrm{L}^{-1}$ of a binary mixture of $\mathrm{CdO}+\mathrm{CuO}$ exposure (Figure 1c).

Compared with the control condition, under both humidities, the accumulation of $\mathrm{Cd}$ and $\mathrm{Cu}$ was significantly increased $(p<0.05)$ with increasing (concentration) metal exposure (Table 4 ). Our two-way ANOVA clearly showed that the accumulation was significantly influenced by the humidity and M-NPs exposure (both single and binary mixture) (Table 5). 
Table 4. Metal accumulation in seedlings of $V$. radiata exposed to $\mathrm{CdO}, \mathrm{CuO}$, and $\mathrm{CdO}+\mathrm{CuO}$ over $48 \mathrm{~h}$ (mg kg ${ }^{-1}$ d.w.). Results are given as mean ${ }^{*} p<0.05$ vs. control) and means following with different letters ( $\mathrm{a}$ to $\mathrm{d}$ ) in each column are significant at $5 \%$ level of probability.

\begin{tabular}{|c|c|c|c|c|c|}
\hline \multirow{2}{*}{\multicolumn{2}{|c|}{ Concentration $\left(\mathrm{mg} \mathrm{L}^{-1}\right)$}} & \multicolumn{2}{|c|}{$80 \%$ humidity } & \multicolumn{2}{|c|}{$70 \%$ humidity } \\
\hline & & $\mathrm{CdO}$ & $\mathrm{CuO}$ & $\mathrm{CdO}$ & $\mathrm{CuO}$ \\
\hline \multicolumn{2}{|c|}{ Control } & $37.67 \pm 2.8^{a}$ & - & $19.70 \pm 1.65^{\mathrm{a}}$ & - \\
\hline \multirow{3}{*}{$\mathrm{CdO}$} & 0.1 & $83.13 \pm 12.1^{b}$ & - & $51.47 \pm 5.50^{b}$ & - \\
\hline & 1 & $100.9 \pm 7.90^{\mathrm{c}}$ & - & $84.29 \pm 10.04^{c}$ & - \\
\hline & 10 & $193.3 \pm 8.02^{\mathrm{d}}$ & - & $126.47 \pm 13.42^{\mathrm{d}}$ & - \\
\hline \multirow[t]{2}{*}{ Control } & & - & $46.0 \pm 8.00^{a}$ & - & $34.6 \pm 9.45^{a}$ \\
\hline & 0.1 & - & $208.5 \pm 0.50^{b}$ & - & $175.1 \pm 6.92^{b}$ \\
\hline \multirow{2}{*}{$\mathrm{CuO}$} & 1 & - & $260.3 \pm 19.9^{c}$ & - & $203.7 \pm 6.86^{c}$ \\
\hline & 10 & - & $317.0 \pm 10.15^{\mathrm{d}}$ & - & $206.4 \pm 22.6^{\mathrm{c}}$ \\
\hline \multirow[t]{2}{*}{ Control } & & $37.67 \pm 2.8^{a}$ & $46.0 \pm 8.00^{a}$ & $19.70 \pm 1.65^{a}$ & $34.6 \pm 9.45^{a}$ \\
\hline & $0.1+0.1$ & $78.8 \pm 13.58^{b}$ & $171.0 \pm 13.58^{c}$ & $72.97 \pm 7.46^{b}$ & $118.7 \pm 6.25^{b}$ \\
\hline \multirow{2}{*}{$\mathrm{CdO}+\mathrm{CuO}$} & $1+1$ & $82.17 \pm 8.14^{b}$ & $91.83 \pm 17.32^{b}$ & $47.67 \pm 15.8^{c}$ & $86.14 \pm 8.47^{c}$ \\
\hline & $10+10$ & $111.3 \pm 13.05^{c}$ & $96.66 \pm 7.15^{b}$ & $91.43 \pm 3.98^{\mathrm{d}}$ & $57.66 \pm 7.53^{d}$ \\
\hline
\end{tabular}

Table 5. Results of two-way ANOVA on the interaction between concentration (CdO, $\mathrm{CuO}$, and $\mathrm{CdO}+\mathrm{CuO})$ and humidity $(80 \%$ and $70 \%)$ on the accumulation of $\mathrm{Cd}$ and $\mathrm{Cu}$ in $\mathrm{V}$. radiata biomass. (Df-degrees of freedom, $\mathrm{F}-\mathrm{F}$ statistic and $\mathrm{P}-p$ value).

\begin{tabular}{ccccc}
\hline Exposure / Accumulation & Source of Variation & Df & F & P \\
\hline \multirow{3}{*}{$\mathrm{CdO} / \mathrm{Cd}$ accumulation } & Concentration & 3 & 245.01 & 0.000 \\
& Humidity & 1 & 89.18 & 0.000 \\
& Concentration vs humidity & 3 & 11.00 & 0.000 \\
\hline \multirow{2}{*}{$\mathrm{CuO} / \mathrm{Cu}$ accumulation } & Concentration & 3 & 368.28 & 0.000 \\
& Humidity & 1 & 107.12 & 0.000 \\
& Concentration vs humidity & 3 & 17.35 & 0.000 \\
\hline \multirow{2}{*}{$\mathrm{CdO}+\mathrm{CuO} / \mathrm{Cd}$ accumulation } & Concentration & 3 & 59.57 & 0.000 \\
& Humidity & 1 & 25.02 & 0.000 \\
& Concentration vs humidity & 3 & 2.25 & 0.121 \\
$\mathrm{CdO}+\mathrm{CuO} / \mathrm{Cu}$ accumulation & Concentration & 3 & 131.38 & 0.000 \\
& Concentration vs humidity & 3 & 80.86 & 0.000 \\
& & & 8.78 & 0.001 \\
\hline
\end{tabular}

\section{Discussion}

Germination is a seed development process that might be influenced by environmental factors such as temperature, humidity, and contaminants in the environment $[17,18]$. Therefore, a germination test was conducted under these environmental factors stress to determine the viability of the seeds [19]. The optimum temperature and humidity for the germination of black gram were reported as $35^{\circ} \mathrm{C}$ and $80 \%$ respectively [16]. Therefore, we selected this temperature $\left(35^{\circ} \mathrm{C}\right)$ and humidity $(80 \%)$, as well as $70 \%$ humidity, as our test conditions. Without M-NPs stress (in control), the germination rate was $100 \%$ at $80 \%$ humidity and $70 \%$ at $70 \%$ humidity. These results are consistent with earlier reports, which have reported a reduction in germination in black gram at $\leq 70 \%$ humidity [16] and the germination in Sesamum indicum at $\leq 70 \%$ humidity [20]. This might be due to the $80 \%$ of humidity ameliorated seed growth and development, which might involve the activities of various plant enzymes and hormones [16,21].

Similar to humidity, the concentration-dependent reduction in seed germination when exposed to M-NPs has been reported by many studies $[9,13]$. There was no inhibition of germination under an M-NPs exposure level of 0.1 to $10 \mathrm{mg} \mathrm{L}^{-1}$ at $80 \%$ humidity test, indicating that $V$. radiata tolerates 
this range of exposure. Similarly, at 70\% humidity, there was no significant difference between control and exposure $(\mathrm{CdO}$ and $\mathrm{CuO})$, except for a high concentration of $\mathrm{CdO}$. However, the germination rate at $70 \%$ humidity was less than at $80 \%$ humidity in all concentrations (after $48 \mathrm{~h}$ ). The similarity of germination between control and exposure was indicated by the value 1 in the calculation of relative germination rate (germination in exposure/germination in control) (Figure 1a-c). The relative germination of $<1$ in this study indicated the negative influence of $\mathrm{CdO}\left(1\right.$ and $\left.10 \mathrm{mg} \mathrm{L}^{-1}\right)$ and $\mathrm{CdO}+$ $\mathrm{CuO}\left(10+10 \mathrm{mg} \mathrm{L}^{-1}\right)$ exposure on seed germination.

The seed coat is a barrier and can have selective permeability, which might protect the embryo from external toxic chemicals and environmental stresses such as temperature and humidity. Many studies have reported the inhibitory effect of M-NPs on plant shoot and root length; however, this may not inhibit the germination rate since they cannot pass through seed coats [22-24]. During germination, the dry seed expands its size due to the imbibition process. This process culminates in the rupture of the seed coat, which might create the opportunity to direct contact with the nanoparticles in the media. This might account for the reduction of the development of seed in all exposures in this study. We detected a considerably lower germination rate under the $70 \%$ humidity condition. This finding was compatible with previous study results [16], where the experiment was conducted without any metal stress.

Even though seed coats offer some protection, in this study, the accumulation of M-NPs in seedlings was increased with increased exposure concentration (Table 4). The accumulation was greatly influenced by the presence of other metals, resulting in a reduction in bioaccumulation under both humidities $(80 \%$ and $70 \%$ ) in the binary mixture of M-NPs (Table 4). Meanwhile, the accumulation of metals at $70 \%$ humidity was less than that at $80 \%$ humidity. In general, the size of the $\mathrm{CuO}$ nanoparticle (1-30 nm) was less than that of the CdO nanoparticle $(20-80 \mathrm{~nm})$ (Table 1). In addition, the solubility of $\mathrm{CdO}$ in water was $4.8 \mathrm{mg} \mathrm{L}^{-1}$. Therefore, the solubility was higher in the exposed concentration of 0.1 and $1 \mathrm{mg} \mathrm{L}^{-1}$. Meanwhile, the nature of $\mathrm{CuO}$ is insoluble in water. Therefore, some of the $\mathrm{CuO}$ NPs might have been able to penetrate the cell wall (cell wall pore size ranged from 1.6 to $4.6 \mathrm{~nm}$ ) and enter the cell as a result, affecting the biological process of the seed. This might account for the higher accumulation of $\mathrm{Cu}$ than $\mathrm{Cd}$ (Table 4). In the case of $\mathrm{CdO}$, since their size (20-80 nm) was greater than the plant cell pore size (1.6 to $4.6 \mathrm{~nm}$ ), initially, CdO might not have entered or entered slowly. The rupture of the seed coat then allowed free entry of the $\mathrm{CdO}$ ions. This might account for the lower accumulation of $\mathrm{Cd}$ than $\mathrm{Cu}$ (Table 4). Later, they entered into seeds through intracellular spaces of parenchymatous tissue, which facilitated its diffusion to cotyledons [25,26]. However, the exact mechanism of $\mathrm{CdO}$ toxicity on germination needs to be further investigated. No other reports are available in the literature that addresses the toxic effect of M-NPs under different humidity conditions.

\section{Conclusions}

The single and binary mixtures of metal-based nanoparticles $(\mathrm{CdO}$ and $\mathrm{CuO})$ on the germination of $V$. radiata were tested at $70 \%$ and $80 \%$ humidity. Germination percent, relative germination rate, and the metal accumulations were the parameters considered in this study after $48 \mathrm{~h}$. The germination rate was lower in binary mixtures than the single metal exposure in both humidity ranges. The relative germination rate did not change by $80 \%$ humidity in all concentrations tested. Meanwhile, the inhibition of the germination rate began from $1 \mathrm{mg} \mathrm{L}^{-1}$ of $\mathrm{CdO}$ and $10+10 \mathrm{mg} \mathrm{L}^{-1}$ of $\mathrm{CdO}+\mathrm{CuO}$ exposures at a $70 \%$ humidity test. The results of two-way ANOVA showed that the accumulation was concentration and humidity dependent. These preliminary results reported here clearly show that the germination rate was controlled by humidity and single and binary mixture of M-NPs (CdO, $\mathrm{CuO}$, and $\mathrm{CdO}+\mathrm{CuO}$ ) exposure. To confirm these findings, further studies are now needed in a pot culture experiment.

Author Contributions: Conceptualization, S.S.; methodology, S.-H.J. and E.S.J.; software, S.S.; validation, S.-C.H., P.-I.Y. and J.-M.S.; formal analysis, E.S.J.; investigation, S.-H.J.; resources, E.S.J.; data curation, S.S.; writing-original draft preparation, S.S.; writing-review and editing, S.S.; visualization, E.S.J.; supervision, S.-C.H. and P.-I.Y.; 
project administration, S.S.; funding acquisition, S.S. All authors have read and agreed to the published version of the manuscript.

Funding: This research received no external funding.

Acknowledgments: This work was supported by a 2-Year Research Grant of Pusan National University.

Conflicts of Interest: The authors declare no conflicts of interest.

\section{References}

1. Navarro, E.; Baun, A.; Behra, R.; Hartmann, N.B.; Filser, J.; Miao, A.J.; Quigg, A.; Santschi, P.H.; Sigg, L. Environmental behavior and ecotoxicity of engineered nanoparticles to algae, plants, and fungi. Ecotoxicology 2008, 17, 372-386. [CrossRef] [PubMed]

2. Kulak, E.; Ognik, K.; Stepniowska, A.; Sembratowicz, I. The effect of administration of silver nanoparticles on silver accumulation in tissues and the immune and antioxidant status of chickens. J. Anim. Feed Sci. 2018, 27, 44-54. [CrossRef]

3. Shvedova, A.A.; Pietroiusti, A.; Fadeel, B.; Kagan, V.E. Mechanisms of carbon nanotube-induced toxicity: Focus on oxidative stress. Toxicol. Appl. Pharmacol. 2012, 261, 121-133. [CrossRef] [PubMed]

4. Setyawati, M.I.; Tay, C.Y.; Leong, D.T. Effect of zinc oxide nanomaterials-induced oxidative stress on the p53 pathway. Biomaterials 2013, 34, 10133-10142. [CrossRef] [PubMed]

5. Rico, C.M.; Majumdar, S.; Duarte-Gardea, M.; Peralta-Videa, J.R.; Gardea-Torresdey, J.L. Interaction of nanoparticles with edible plants and their possible implications in the food chain. J. Agric. Food Chem. 2011, 59, 3485-3498. [CrossRef]

6. Miralles, P.; Church, T.L.; Harris, A.T. Toxicity, uptake, and translocation of engineered nanomaterials in vascular plants. Environ. Sci. Technol. 2012, 46, 9224-9239. [CrossRef]

7. Lee, H.L.; Mohammed, I.A.; Belmahi, M.; Assouar, M.B.; Rinnert, H.; Alnot, M. Thermal and optical properties of cds nanoparticles in thermotropic liquid crystal monomers. Materials (Basel) 2010, 3, 2069-2086. [CrossRef]

8. Kumbhakar, D.V.; Datta, A.K.; Mandal, A.; Das, D.; Gupta, S.; Ghosh, B.; Halder, S.; Dey, S. Effectivity of copper and cadmium sulphide nanoparticles in mitotic and meiotic cells of Nigella sativa L. (black cumin)—Can nanoparticles act as mutagenic agents? J. Exp. Nanosci. 2016, 11, 823-839. [CrossRef]

9. Ghosh, B.; Datta, A.K.; Pramanik, A.; Kumbhakar, D.V.; Das, D.; Paul, R.; Biswas, J. Mutagenic Effectivity of Cadmium Sulphide and Copper Oxide Nanoparticles on Some Physiological and Cytological Attributes of Lathyrus sativus L. Cytologia 2017, 82, 267-271. [CrossRef]

10. Atha, D.H.; Wang, H.; Petersen, E.J.; Cleveland, D.; Holbrook, R.D.; Jaruga, P.; Dizdaroglu, M.; Xing, B.; Nelson, B.C. Copper oxide nanoparticle mediated DNA damage in terrestrial plant models. Environ. Sci. Technol. 2012, 46, 1819-1827. [CrossRef]

11. Shaymurat, T.; Gu, J.; Xu, C.; Yang, Z.; Zhao, Q.; Liu, Y.; Liu, Y. Phytotoxic and genotoxic effects of ZnO nanoparticles on garlic (Allium sativum L.): A morphological study. Nanotoxicology 2012, 6, 241-248. [CrossRef] [PubMed]

12. Mohanty, B. Design and Construction of a Modified Rapid Sand Filter for Treatment of Raw Water. J. Res. 2017, 3, 9-13.

13. Hoe, P.T.; Mai, N.C.; Lien, L.Q.; Ban, N.K.; Van Minh, C.; Chau, N.H.; Buu, N.Q.; Hien, D.T.; Van, N.T.; Hien, L.T.T.; et al. Germination responses of soybean seeds under $\mathrm{Fe}, \mathrm{ZnO}, \mathrm{Cu}$ and $\mathrm{Co}$ nanoparticle treatments. Int. J. Agric. Biol. 2018, 20, 1562-1568.

14. Ko, K.-S.; Koh, D.-C.; Kong, I. Evaluation of the Effects of Nanoparticle Mixtures on Brassica Seed Germination and Bacterial Bioluminescence Activity Based on the Theory of Probability. Nanomaterials 2017, 7, 344. [CrossRef]

15. Shahid, M.; Dumat, C.; Khalid, S.; Schreck, E.; Xiong, T.; Niazi, N.K. Foliar heavy metal uptake, toxicity and detoxification in plants: A comparison of foliar and root metal uptake. J. Hazard. Mater. 2017, 325, 36-58. [CrossRef]

16. Limwiwattana, D.; Tongkhao, K.; Na Jom, K. Effect of Sprouting Temperature and Air Relative Humidity on Metabolic Profiles of Sprouting Black Gram (Vigna mungo L.). J. Food Process. Preserv. 2016, 40, 306-315. [CrossRef] 
17. Pramanik, A.; Datta, A.K.; Das, D.; Kumbhakar, D.V.; Ghosh, B.; Mandal, A.; Gupta, S.; Saha, A.; Sengupta, S. Assessment of Nanotoxicity (Cadmium Sulphide and Copper Oxide) Using Cytogenetical Parameters in Coriandrum sativum L. (Apiaceae). Cytol. Genet. 2018, 52, 299-308. [CrossRef]

18. Zhang, D.; Liu, X.; Chen, F.Q. Effects of Temperature and Humidity on the Germination of Two Pioneer Species in Ecological Restoration. Appl. Mech. Mater. 2012, 209-211, 1265-1268. [CrossRef]

19. Das, D.; Datta, A.K.; Kumbhakar, D.V.; Ghosh, B.; Pramanik, A.; Gupta, S. Nanoparticle (Cds) interaction with host (sesamum indicum 1.) - Its localization, transportation, stress induction and genotoxicity. J. Plant Interact. 2018, 13, 182-194. [CrossRef]

20. Hahm, T.S.; Park, S.J.; Martin Lo, Y. Effects of germination on chemical composition and functional properties of sesame (Sesamum indicum L.) seeds. Bioresour. Technol. 2009, 100, 1643-1647. [CrossRef]

21. Chhun, T.; Uno, Y.; Taketa, S.; Azuma, T.; Ichii, M.; Okamoto, T.; Tsurumi, S. Saturated humidity accelerates lateral root development in rice (Oryza sativa L.) seedlings by increasing phloem-based auxin transport. J. Exp. Bot. 2007, 58, 1695-1704. [CrossRef] [PubMed]

22. Adhikari, T.; Kundu, S.; Biswas, A.K.; Kundu, S.; Tarafdar, J.C.; Rao, A.S. Effect of copper oxide nano particle on seed germination of selected crops. J. Agric. Sci. Technol. A 2012, 2, 815-823.

23. Dhoke, S.K.; Mahajan, P.; Kamble, R.; Khanna, A. Effect of nanoparticles suspension on the growth of mung (Vigna radiata) seedlings by foliar spray method. Nanotechnol. Dev. 2013, 3, 1. [CrossRef]

24. Hajra, A.; Mondal, N.K. Effects of $\mathrm{ZnO}$ and $\mathrm{TiO} 2$ nanoparticles on germination, biochemical and morphoanatomical attributes of Cicer arietinum L. Energy Ecol. Environ. 2017, 2, 277-288. [CrossRef]

25. Lee, C.W.; Mahendra, S.; Zodrow, K.; Li, D.; Tsai, Y.C.; Braam, J.; Alvarez, P.J.J. Developmental phytotoxicity of metal oxide nanoparticles to Arabidopsis thaliana. Environ. Toxicol. Chem. 2010, 29, 669-675. [CrossRef] [PubMed]

26. Ma, Y.; Kuang, L.; He, X.; Bai, W.; Ding, Y.; Zhang, Z.; Zhao, Y.; Chai, Z. Effects of rare earth oxide nanoparticles on root elongation of plants. Chemosphere 2010, 78, 273-279. [CrossRef] [PubMed]

(C) 2020 by the authors. Licensee MDPI, Basel, Switzerland. This article is an open access article distributed under the terms and conditions of the Creative Commons Attribution (CC BY) license (http://creativecommons.org/licenses/by/4.0/). 